\title{
Election, 2017
}

\section{Khem K. Aryal Associate Professor of English, Arkansas State University, USA}

Topbahadur read on his cell phone that the government had finally declared dates for legislative elections to elect members of the House of Representatives and provincial assemblies under a new constitution his party had fought a long war for. The sensation he'd experienced during the 1991 election, the first election after the restoration of multiparty democracy, returned afresh. He was only a teenager then and didn't have any stakes in politics yet, but the election had paved his way to politics, and in a few years he'd joined the Maoist party waging an armed revolt against the monarchical regime. He had survived the decade-long war, spent a few uncertain years in a Maoist camp following a peace agreement with the government, and flown to America, feeling lost. Now that the transition seemed to be ending in the country and they seemed to be getting what the party had fought for, wasn't it time to be home?

"Soonmaya, listen," he spoke to his wife, his eyes still on the screen, "I'm going to Nepal to run for election."

"I leave you," Soonmaya replied promptly in her Chinese accent, "before you get out of the bathroom."

He re-read the news, his heart beating faster. He should never have left the country in the first place, he mused. He also told himself that he could have restrained himself a bit more during the rebellion. He had no more stakes than the rest who had joined the fight, and there was no need to go an extra mile to prove that he was brave enough to do anything for the sake of the country.

"Go back to school," said Soonmaya with a single knock on the bathroom door as if wanting to make sure that he heard. "I see your election last time," she added.

"That was no election," he replied. "They can't be compared." school.

"You lose it," Soonmaya said, and threatened again to leave him if he didn't go back to

Topbahadur wanted to speak to somebody from Nepal right away. It was such an exciting moment. The thrill of the election aside, his sudden awareness that he was going to be such an eligible candidate for the House representing his district almost crippled him. Who could he talk to about the possibility? Would any of them request that he return to contest the election?

He sat on the commode staring at the phone screen until both his legs went numb. The initial excitement gradually waned, giving way to depression as no contact appeared handy for him to call. He scrolled down the contact list and then up and then down again. No, there still 
appeared to be nobody he could comfortably call to announce his candidacy. Had he been so severely distanced from his comrades already?

Topbahadur had left the country six years before, and had hardly maintained his contact with the party ranks. He'd been a deserter in a way, and his comrades were right to despise him, though some of them had supported his move; they'd said one had to think about their life and at some point make decisions that might not make everyone happy. He had done his partsacrificed his career as a primary teacher, fought a war for the country, and, when the fighters were confined to camps, decided to move on and think about his own future. But who knew! He probably would have stayed back had he not been confined to a camp, without anything to do but reflect on the acts that felt perfectly normal and necessary while in the midst of the war but now haunted him every night. His senior ex-colleague had been a regular visitor in his dreams, often gripping his throat: "Topbahadur sir, you betrayed me, an old man!" He knew it must have been a big deal that a district level deputy commander of the party had left the country secretly. Once in America, he'd called one of his comrades to let him know that he'd safely arrived in the new land. "Badhai, comrade," the colleague had ridiculed him. "You surrendered to the imperialist power that we fought together. Gari khanus!" Do well for yourself! His effort to explain that he was still committed to the ideals of their rebellion had been useless. Within a few months of his arrival, he'd filed for asylum, claiming that he'd fled the country because of the Maoist threat. He was amazed at how neatly the attorney's office produced necessary documents, including news articles where his name appeared as a victim of the internal conflict that had plagued the country. His heart had stopped for a few seconds when he signed the application form, I-589, but then he had told himself that it was only a formality. He still believed in the fight, and he hadn't betrayed his country.

As the transition became prolonged, leaving the fighters in limbo, some had called him and said he' $d$ taken the right decision just in time. Ironically though, he' $d$ begun to miss the fight he'd fought and the country that he believed he loved; he wanted them to at least wish that he would return. Working at a grocery store, with no dignity and no change of fortune in the foreseeable future, was much less satisfying than the thrill of the romantic ideal of fighting for the country. The fact that the party had become a major player in the country's politics and the most important election was happening now made Topbahadur suffocate the whole day at Bill's Grocery as he scanned packets of chicken quarters and bleated to his customers, "Have a good day, sir," "Have a good day, Ma’am."

That evening he began to make a list of possible candidates from his district. The left parties would have a common candidate even though they hadn't merged their parties yet. Would they pick the same leader who had been elected right after the 1990 revolution again? That would be disastrous, he thought. The candidate had to come from a new generation of leaders, and there were many eligible candidates. Had the district commander of the Maoists remained loyal to the party, he'd probably claim for the ticket, and nobody would challenge him. After him, Topbahadur himself was the most eligible person. Second to him would come Gangaram. He'd joined the Maoist party a little later, but they'd fought the war together. There was one Bijaylal Gairey too, but he came from another faction of the left, and he'd been an arrogant ass 
in Topbahadur's estimation, so he didn't want to consider the man for the candidacy. If he were still in Nepal and the party nominated Bijaylal as the candidate, Topbahadur thought, he'd probably revolt and announce his own candidacy.

Topbahadur passed a few days wondering where to start. Despite his hopes, nobody had called him yet, either from Nepal or from America, where Nepali politics had become no less enthralling than in Nepal. It was then that he thought of calling Rudramani, his one-time acquaintance, who had contested an election of non-resident Nepalis, called NRNs, along with Topbahadur. (Both had been defeated. Rudramani had moved to Baltimore from St. Louis right after the election and Topbahadur hardly had any contact with him since then.) What could Rudramani be thinking of the election? Topbahadur asked himself. Should he call him? Then one day he decided to call somebody from his own party in Nepal.

"Oho," said Kulprasad, caught off-guard. "You called at the right time. We need your help."

Topbahadur briefly regretted his decision to call the man. There was no big surprise at the call, no thank you, no how are you doing, no when are you coming to Nepal. Nothing.

"Sure," said Topbahadur nonetheless. He said he was ready to do anything he could to help the party. Some might have thought that he had been a bhagauda, a run-away, but he always thought of the country and the party, and he was readily available to help.

The enthusiastic Kulprasad said he was sure to win the election if he got the nomination from his party.

"You have my full support," said Topbahadur. "How is Gangaram's possibility?"

Kulprasad dismissed Gangaram as a non-competitor. Topbahadur didn’t ask about Bijaylal.

After he hung up, Topbahadur felt even more alone. That ass Kulprasad didn't even ask him once to return and contest the election. He could at least tell him that Topbahadur Bhat was the most eligible man and the country needed him. He had fought for the country and he deserved the party's ticket in the election.

The pain of his defeat in the NRN election two years ago resurfaced. "Soonmaya," he said to his wife, "I think I'd get the ticket if I were still in Nepal."

"But you are not," she said matter-of-factly. "Like I'm not in China anymore."

Topbahadur had met Soonmaya at an Indian cultural event, called India Night, at a local

university, where she'd been a nursing student. Her Chinese name was Chao-Xing, and on realizing that he was attracted to the girl but couldn't pronounce her name correctly, he'd asked her, "Can I give you a Nepali name?" And the girl had understood it to be a proposal for a date or something. She'd then asked when he wanted to meet and where. They had their first date at the Gateway Arch in St. Louis, where he'd named her "Sun-maya" upon learning that her name meant morning star, and later changed it to "Soonmaya," meaning "gold love" as well as "listen, love" in his native language. During their first date, he'd asked her about the Communist Party of China, Mao Zedong, and the progress the country was making. When she'd expressed her ignorance, he'd given her a lesson on her own country. As if desperately needing a break, she'd blurted, "Make me your wife," and they'd got married within the next two months. 
That had further estranged Topbahadur from whatever connections he had so far maintained, including with his family back in Nepal. Soonmaya had siezed the opportunity to convince him to join a community college but he'd dropped it after a year. When the NRN election happened in the city, he'd tried to revive his political life, but that had backfired; even those who didn't know him well didn't hesitate to call him a war criminal behind his back, which he told himself was grossly unfair.

"But listen," Topbahadur said to Soonmaya, "I'm a political man. I'm already past my college age."

"I leave you," Soonmaya put it straight, "if you don't go back to school." Topbahadur

never understood it when she said she'd leave him if he didn't do this or

that. He liked the frivolity though. It was one of the things that had encouraged him to get married to her. He believed that he was still on the move, didn't know where he'd end up next, Nepal always at the back of his mind, and so he didn't want to make a lifelong commitment. Marrying the girl who seemed to be from a distant world - with no family and no relatives to know and to meet, from as far away as China-felt like making no commitment at all. But when she said she'd leave him, he felt conflicted, as it made him love her more.

Following the call with Kulprasad, Topbahadur spent the next few weeks devising strategies to win the election if he went back and got the ticket. Then one day he got an email sent by Rudramani to Rudramani himself.

Rudramani came from his own district back in Nepal, a few hours' walk away from Topbahadur's village. They'd worked for the same left party until the Maoists launched an armed rebellion that Topbahadur ended up joining, and when they met in St. Louis after a gap of many years, their parties were again coming together. Rudramani had thick hair that he used to hide his brow, and he smirked all the time, as if saying condescendingly, "I'm your default leader; you guys have got to support me." From the way he behaved, Topbahadur suspected that his smile was in fact a fault in his countenance, maybe his lips, that made him look like he was smiling all the time despite being an asshole.

The email began with "Respected friends," which immediately evoked to Topbahadur the way the party leaders addressed the masses back in Nepal, "Aadarniya saathiharu!" That asshole, thought Topbahadur. He's acting like a leader. He again clicked on the address to see who else the email had been addressed to, and there again he saw only Rudramani Neaupane- of course, the email had undisclosed recipients.

The body of the email stated that Nepal was going through exciting times. It had been possible only because of hundreds of people like them-Topbahadur wanted to know again who those other people were-who had made sacrifices, and then Rudramani thanked everyone for those sacrifices.

Topbahadur paused. Had Rudramani become such a big-shot leader already? What had he done in America since he moved to Baltimore two years ago? Topbahadur opened a new window on the Internet and checked on Facebook to see more about the man. There he found that his friends had congratulated him on getting admitted to a Ph.D. program. He also found a new link to an online news site that reported on his admission to Ph.D., the research he was going to conduct, and his plans to give back to the community. It confused Topbahadur a little. News 
about somebody getting admitted to a Ph.D. program at a third grade university? He also found that Rudramani had been posting on politics, had shared links to the news from Nepal, and had pictures taken with leaders from Nepal - in all of them his lower lip faking a smile.

The rest of the email was about the need to come together, support the left candidate back home in the election. Every one of them had to do whatever they could from wherever they were. Soon there would be a fundraising campaign, he wrote, and they were expected to contribute as much as they could. There was also a possibility that they could organize a gathering in the near future to further discuss how they could help their candidate better.

"Listen, Soonmaya," Topbahadur said, preparing to leave for work.

"I'm listening," said Soonmaya.

"Listen," said Topbahadur, "I love my country."

"What country?" she asked. "Which country is your country?"

"Certainly not China," he replied.

Soonmaya spoke a few sentences in Chinese, which to Topbahadur meant only a friendly complaint, and they both laughed. This sense of humor he'd discovered only after their marriage had helped them develop a new bonding.

"Sadak-Chhap have become leaders already," he said, gravely. "He'd come nowhere near me in the party portfolio."

Soonmaya again spoke in Chinese. He knew she wanted him only to return to school and get a degree.

That whole day Topbahadur composed an email in his mind. He had to top that asshole Rudramani, who'd acted as if it was his party, and Topbahadur was his follower, whereas it had to be the other way round. In the email he'd speak of the party in more detail, give some historical context - Rudramani's email lacked data—and make much bigger claims and promises and calls to all Nepali people in North America to come together and support the candidate. Wouldn't that force Rudramani back in his place?

He became aware of a problem, though, when he sat in front of the computer. That ass Rudramani had hidden the email addresses. What was the point of replying only to him?

"Rudramani!" he wrote nonetheless. "This is a good initiative but let me speak with some friends before raising funds or planning for a meeting. I'm glad you're with us in this effort to help our candidate win."

Rudramani shot back an email within an hour, thanking Topbahadur for his prompt response, and said that comrades like him inspired him to keep working for the party even in America. He was confident that they would win the election with flying colors.

"Listen, Soonmaya," said Topbahadur to his wife.

"I'm listening," replied Soonmaya as expected.

"This man is an asshole," he said.

"Why are you after him?" asked Soonmaya. "Go back to school; you don't have to see his A-hole."

Topbahadur began to call the people he believed would listen to him over Rudramani; after all, being a leader meant asserting your leadership; nobody was going to come to him 
asking him to lead them. Some of them said they were happy that Topbahadur hadn't forgotten his party, and others made him feel how much out of touch with reality he had been in those few years. One of the younger boys said, "Seniors like you should not stay passive and see the world burn. You have to get more involved and help us. I'm happy that you called me; I was planning to call you myself. Keep in touch, Dai."

Topbahadur called Rudramani finally.

"Topbahadur Bhai," replied Rudramani.

Wait! When did he become Rudramani's younger brother? What did that asshole think of himself? Topbahadur hung up the phone right then and waited, as if to let himself calm down. As he was still struggling to make sense of Rudramani's arrogance, he received a call back.

Rudramani said sorry that the phone had been disconnected, his network was not reliable but he was glad that Topbahadur was still loyal to the left parties and he hadn't forgotten his country. "What difference does it make that one has married a foreigner?" he said. "You don't become a bhagauda, that is more important. You don't quit." forget that?"

"Listen, Rudramani," said Topbahadur. "I was your senior in politics in Nepal. Did you

"Does that even matter?" asked Rudramani. "We are not doing politics here. We are trying to help our friends in Nepal."

Then Topbahadur said he could be the candidate for the House of Representatives had he stayed back. He could claim the ticket if he went back even now.

Rudramani laughed, a bit hysterically. "Topbahadur," he said, "you are no more on the list. The parties have forgotten you. You married a foreigner and stayed out of touch for a long time. That disqualifies you instantly. You have to understand that."

The argument resulted in vitriol. They challenged each other to show what they could do. Each accused the other of dumping their country and pledging their loyalty to the American flag and pretending to love the country they'd left behind more than the country they'd adopted. Both accused each other of being a hypocrite. Then there was a silence. behind."

"Soonmaya!" Topbahadur turned to his wife after he'd calmed down. "I'm falling

"Go back to school; get a degree," said Soonmaya.

"I'm talking about politics," he said.

"I leave you," said Soonmaya and began her Chinese rambling.

In the weeks that followed, Topbahadur spoke to more people on the phone, at times mentioning that he could be the party's candidate had he stayed back. "Of course," said some and that made him miss the election more. He'd probably have stayed back had he known that the transition could actually end one day. Had there been some ray of hope, he'd have continued doing politics. Very soon they'd decide on the candidates and make their nomination. The candidates would strut with a celebratory procession to the nomination office amid a shower of jaijaikar. Much excitement and hope. He'd spent his youth fighting for the party, and when it was time to reap what he had sowed, he'd been self-exiled, now working at Bill's, selling pork ribs and Coca-Cola cans to people who never gave a shit about him even though he never failed to wish them a good day. 
Soon it became clear that there were two camps of people in North America from the left parties, lobbying for two different candidates back in Nepal. Of some twenty-five people who were active, some followed Rudramani while the others listened to Topbahadur. The two camps promised to use all possible means to get their candidate of choice nominated, and the fight reached a point where somebody suggested that if they fought the way they did, the opposition party would win the election. Then somebody suggested that both the camps come together and decide on one candidate. Topbahadur seized the opportunity and proposed that they meet at a hotel in Dallas, where most people from the district seemed to reside.

"We're supposed to travel to Texas to decide on a candidate in Nepal?" asked one in a mass email from Rochester. "Who's going to pay for the airfare and hotel?"

"Send the money to the party instead," suggested another from Northridge.

"Those who don't have better things to do can go and waste their time and money," wrote one form Omaha.

The gathering never happened, but Topbahadur heard very soon that Rudramani had arranged a meeting of like-minded people at his home in Baltimore. People had driven up to three hours to participate, had a barbeque party, and left in the evening. They had pledged to support Bijaylal for the candidacy, and most of them had volunteered to contribute cash if he got nominated. Topbahadur also heard that Rudramani planned to travel to Nepal to support the candidate.

One Somprasad from Denver showed his concern about groupism. "We show Nepalipara wherever we go," he wrote. "When will we free ourselves from goot-bandhi? I have no interest in this type of politics. Please remove me from the mailing list. Jaya hos!"

More people opted out of the list in the coming days, but those who remained evolved into a more combative creed. One Danbahadur wrote from Columbia, Missouri, "We will show in the NRN election. We have kept the record of each and every one."

The more Topbahadur watched the fallout of what he believed could be his base, the more he wanted to stand for the election himself. The thrill, the sensation, the prospect of politics in Nepal! After all, he'd fought so much for the country. He could have been killed any moment all those years he fought for the underground party. It was a shame that he'd left the country when the transition was near complete. Why had he risked his life if he had to leave the country after all? That too to come to America? A country that they designated as number one enemy of the people of the world?

As the nomination day neared in Nepal, there were fights, character smearing campaigns all around, and in America, they kept hurling insults at the ones who didn't belong to their camp. In the midst of this, Topbahadur received an email that disparaged him for acting as if he still had any relevance despite marrying a foreigner, and a Chinese woman at that. Not a new allegation, but something to come from Rudramani himself as a dismissal was painful. In an impassioned reply, Topbahadur reminded everyone that Rudramani had become an American citizen already, and questioned what ethics allowed him to act like a genuine Nepali working for Nepal's prosperity. That didn't fare quite well though; most of the people on the list had already pledged loyalty to the American flag, and Topbahadur had forgotten that fact. 
"You know," Topbahadur said, putting away his phone when his manager walked toward him a couple of days before the nomination day in Nepal, "my country is holding an election soon."

"Election?" said the manager, a middle-aged man who seemed to have piled all his food around his waist, his belt neatly separating the lower torso with the upper one covered in a white shirt and a blue tie. "Elections are good," he added, and picked a couple items that lay around the belt. "Oh, you have elections too? What country did you say you come from?"

Of course, Topbahadur said, they had elections. His was a democratic country too; he had fought for democracy personally, risked his life raising weapons against monarchy. But he didn't feel like repeating to the guy where he came from. Every couple of weeks, the man asked him if he was from some country in the Middle East.

"It's a very important election," said Topbahadur, but by that time the man was already gone.

"Son," spoke an elderly man in the checkout line, "I hear you rambling abnormally. I believe it's an act of Satan. There are ways to be saved. Come with me to my church."

"Satan?" Topbahadur asked. "It's the election," he said, laughing. "We're going to have an election in my country. You know, I'm from the country where Buddha was born. Buddha! The enlightened one. Peace! you know, the man of peace!"

The old man said Jesus was the one who saved everyone.

Topbahadur had the urge to say that he was a communist but then he realized that it was America. Those who'd come to America had renounced being communists, at least on paper, the moment they applied for a visa, no matter what hard party liners they might have been back in their country.

The evening before the nomination day, early morning in America- the time difference being almost twelve hours-Topbahadur spoke with a couple of friends and expressed his frustration that the parties hadn't decided on any candidate yet. "They can't pick a right person until the last minute, how will they will the election?" he asked. Then he reiterated there was no better person than Gangaram. He was the man, he said, who could win over the opposition and lead the left parties.

He keenly waited for any new information the whole day he worked at Bill's. It was understandable that the party leaders were going to meet the whole night to decide on the candidate. All the party workers would be lobbying for this or that candidate, or for themselves. Some would be lobbying from Kathmandu, constantly trying to please the top leadership; the others would be trying to pressure from the grassroots level. Yet others would be trying to create pressure using money and even others from foreign lands, in many cases a combination of many of these strategies. He tried to imagine a position for himself-he was worried about his country even though he was far away. He wanted the best for the country, he told himself.

By evening on nomination day, he'd been drained of all his energy. It was then that he got an email from Rudramani. He'd written to thank everyone that Bijaylal was almost certain to get the ticket. Everyone's effort in America seemed to work. Now they'd have to work together to make sure that he would win the general election. 
"Has it been decided?" Topbahadur asked one of his supporters. And the next minute he was replying to all, "Nothing as such has happened. Nobody has to count unhatched chickens."

"Nobody is counting unhatched chickens," was part of the reply he received from Rudramani. "Some people in America were unnecessarily conspiring against legitimate candidates, and it's not going to fare well," the reply added.

"Some people are using the language that could be taken as a threat. We are in America," read part of Topbahadur's reply email.

"Nobody is threatening anybody," came another reply. "We have fought for democracy; we have made sacrifices; we know what we are doing."

"Show winning a seat at a local NGO, or NRN," went the reply.

"You're good enough only to form a union of the husbands of Chinese wives and become its advisor," said another reply. "Best of luck!"

"Why are you showing us this jarta?" a new person popped in. "Why do you include us in your dirty fight? Take me off the email list right away, or I'll block both of you."

Then some other emails said what they'd learnt in Nepal would hardly go away. Some said they had to be united at least in this foreign land.

After midnight, afternoon in Nepal, a photo popped up on Facebook. This man's face had been smeared with vermillion, and garlands concealed his lower face. He wore a dhaka cap in a style Topbahadur thought he recognized. Wasn't it Dalbahadur? What was he doing there? Topbahadur looked closely to make sure that the picture hadn't been posted years ago.

It wasn't. The man had been nominated by the party, and he was going to contest the election and probably win and represent the people from Topbahadur and Rudramani's district.

"Soonmaya," cried Topbahadur. "Give me a glass of water."

Soonmaya was asleep. He called her again, but there was no sign that she'd wake up. An image began to hover in front of him in the dark: a senior colleague of his, whom Topbahadur had lured out of his house and led to a forest, where he'd handed him to his comrades. The elderly teacher had said, "I want Topbahadur sir to shoot me if I have to be shot. Bring him here! If he is not a coward." Topbahadur was hiding behind a tree, unable to face the old man's twinkling eyes. His boys were preparing to deliver what the Maoists said was the people's justice for his crimes of spying against Maoist fighters. "Bring him here," the man had cried, and Topbahadur had left the scene. The villagers had found the poor teacher's body staked to a tree, his head resting on his left shoulder, four days later.

"I didn't kill him," blurted Topbahadur in Nepali. "It was the war that killed the man." He glanced at Soonmaya, who seemed to be in a deep sleep. "I could be me," he said. "But what's the point? You fight for a decade, abolish the monarchy, change the system, and they install the same people who failed you decades ago. What's the point?"

He briefly thought about sending everyone an email with the picture of the man, with the subject line "Congratulations!" He could ask in the email, "Do any of you still regret leaving Nepal? Do you still have the hope for the country?"

Soonmaya was grave when she appeared with two cups of coffee the following morning. Are you okay? he wanted to ask. It was not likely that she was sad because he was defeated in the 
election without being able to even participate. Never had she shown any sympathy for all his craving for politics, his love for the country he had left behind. Why would she? He had only hurt her feelings, not listening to her, only talking of his own country but never asking about the country she had left behind, her family and home.

"Drink your coffee," she said, instead of asking him to go back to school.

"Listen Soonmaya," Topbahadur said, and stopped.

"I know you don't want to go back to school," she said. "That's okay."

"But listen," said Topbahadur. "Everybody loves their country, don't they?" he asked. "Don't you remember your country?"

Soonmaya kept drinking her coffee.

"You have your country too," said Topbahadur. He thought for a while as she maintained silence, and added, "But you don't have elections like we do," and he faked a smile.

"Teach me Nepali," she spoke finally. "I hear you speak last night."

At Bill's that afternoon, Topbahadur felt a sudden urge to talk to the elderly man who'd invited him a few days ago to his church. "At your church," said Topbahadur as the old man approached the counter, "there's a thing called confession, don't they?"

The man stared at him as if he'd been insulted by being asked to rescue a criminal who had no chances of redemption, and reluctantly tossed a packet of pork ribs and a Coca-Cola box toward him.

"I'm going back to school," bleated Topbahadur, scanning the items.

"Good for you," said the old man, equally nonchalant.

"How about NRN election?" Topbahadur asked himself as he drove home after work. 